Environmental Pollution

February 2018, Volume 233 Pages 844-854

http://dx.doi.org/10.1016/i.envpol.2017.11.015

http://archimer.ifremer.fr/doc/00410/52111/

(C) 2017 Elsevier Ltd. All rights reserved

\title{
Oligotrophy as a major driver of mercury bioaccumulation in medium-to high-trophic level consumers: A marine ecosystem-comparative study
}

\author{
Chouvelon Tiphaine ${ }^{1,{ }^{*}}$, Cresson Pierre ${ }^{2,3}$, Bouchoucha Marc ${ }^{2}$, Brach-Papa Christophe ${ }^{1,2}$, \\ Bustamante Paco ${ }^{4}$, Crochet Sylvette ${ }^{1}$, Marco-Miralles Françoise ${ }^{2}$, Thomas Bastien ${ }^{1}$, Knoery Joel ${ }^{1}$
}

${ }^{1}$ IFREMER, Unité Biogéochimie et Écotoxicologie, Laboratoire de Biogéochimie des Contaminants Métalliques, Rue de l'lle d'Yeu, BP 21105, 44311 Nantes Cedex 03, France

2 IFREMER, Unité Littoral, Laboratoire Environnement Ressources Provence Azur Corse, Zone portuaire de Brégaillon, CS 20330, 83507 La Seyne sur Mer Cedex, France

${ }^{3}$ IFREMER, Unité Halieutique de Manche-Mer du Nord, Laboratoire Ressources Halieutiques de Boulogne, 150 quai Gambetta, 62200 Boulogne sur Mer, France

${ }^{4}$ Littoral Environnement et Sociétés (LIENSs), UMR 7266 CNRS-Université de La Rochelle, 2 rue Olympe de Gouges, 17042 La Rochelle Cedex 01, France

*Corresponding author : Tiphaine Chouvelon, email address : tiphaine.chouvelon@ifremer.fr

\begin{abstract}
:
Mercury $(\mathrm{Hg})$ is a global contaminant of environmental concern. Numerous factors influencing its bioaccumulation in marine organisms have already been described at both individual and species levels (e.g., size or age, habitat, trophic level). However, few studies have compared the trophic characteristics of ecosystems to explain underlying mechanisms of differences in $\mathrm{Hg}$ bioaccumulation and biomagnification among food webs and systems. The present study aimed at investigating the potential primary role of the trophic status of systems on $\mathrm{Hg}$ bioaccumulation and biomagnification in temperate marine food webs, as shown by their medium-to high-trophic level consumers. It used data from samples collected at the shelf-edge (i.e. offshore organisms) in two contrasted ecosystems: the Bay of Biscay in the North-East Atlantic Ocean and the Gulf of Lion in the North-West Mediterranean Sea. Seven species including crustaceans, sharks and teleost fish, previously analysed for their total mercury $(\mathrm{T}-\mathrm{Hg})$ concentrations and their stable carbon and nitrogen isotope compositions, were considered for a meta-analysis. In addition, methylated mercury forms (or methyl-mercury, Me-Hg) were analysed. Mediterranean organisms presented systematically lower sizes than Atlantic ones, and lower $\delta 13 \mathrm{C}$ and $\delta 15 \mathrm{~N}$ values, the latter values especially highlighting the more oligotrophic character of Mediterranean waters. Mediterranean individuals also showed significantly higher $\mathrm{T}-\mathrm{Hg}$ and $\mathrm{Me}-\mathrm{Hg}$ concentrations. Conversely, $\mathrm{Me}-\mathrm{Hg} / \mathrm{T}-\mathrm{Hg}$ ratios were higher than $85 \%$ for all species, and quite similar between systems. Finally, the biomagnification power of $\mathrm{Hg}$ was different between systems when considering $\mathrm{T}-\mathrm{Hg}$, but not when considering $\mathrm{Me}-\mathrm{Hg}$, and was not different between the $\mathrm{Hg}$ forms within a given system. Overall, the different parameters showed the crucial role of the low primary productivity and its effects rippling through the compared ecosystems in the higher $\mathrm{Hg}$ bioaccumulation seen in organisms from oligotrophic Mediterranean waters.
\end{abstract}




\section{Graphical abstract}

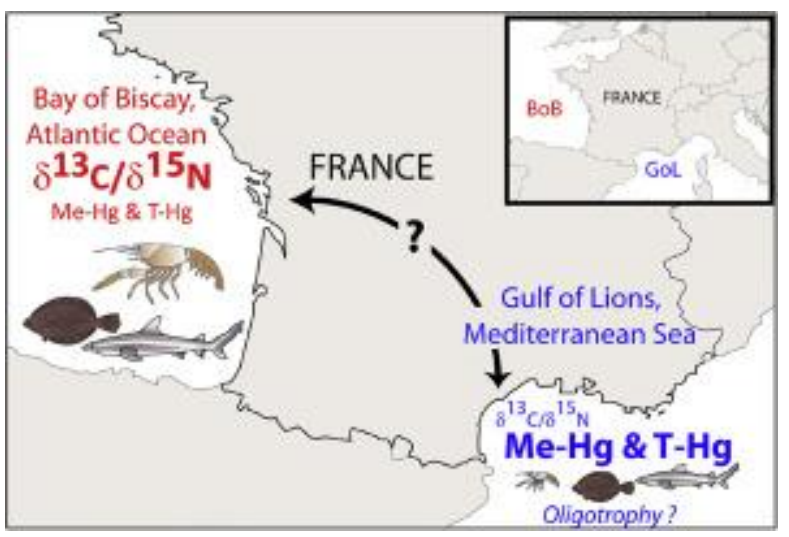

\section{Highlights}

Seven offshore species from the Mediterranean Sea and the Atlantic Ocean examined. Individual sizes, $\delta^{13} \mathrm{C}$ and $\delta^{15} \mathrm{~N}$ values, $\mathrm{Hg}$ concentrations and speciation compared. Mediterranean and Atlantic organisms differed for most of the parameters studied. $\rightarrow \delta^{15} \mathrm{~N}$ values reflected the different trophic status at the base of the two systems. Oligotrophy likely drives the higher $\mathrm{Hg}$ bioaccumulation by Mediterranean organisms.

Keywords : Biomagnifying metal, Bioaccumulation, Trophic status, Ecosystem productivity, Temperate systems 
Mercury $(\mathrm{Hg})$ is released into the environment from both natural and anthropogenic sources (e.g., volcanism, fuel and waste combustion). It reaches marine waters through atmospheric depositions and riverine inputs, the former being the main source of $\mathrm{Hg}$ for the surface ocean (Fitzgerald et al., 2007). Also, Hg is volatile and as such it can be transported through the atmosphere over long distances and deposited in areas away from its point sources. In the ocean, trophic transfer represents the main pathway for the intake and bioaccumulation of $\mathrm{Hg}$ by marine organisms. $\mathrm{Hg}$ exhibits a specific behaviour compared to other trace metals, as it biomagnifies through food webs in its organic methyl- $\mathrm{Hg}$ (Me-Hg) forms (Chen et al., 2008). Finally, $\mathrm{Hg}$ is of particular environmental concern because of its toxicity on the nervous, reproductive, immunological and hormonal systems, sometimes leading to harmful effects at the population level (Boening, 2000; Tan et al., 2009, Goutte et al., 2014).

The methylation of $\mathrm{Hg}$ by microorganisms into $\mathrm{Me}-\mathrm{Hg}$ is the fundamental process giving this contaminant its bioaccumulation and biomagnification properties. In the marine environment, $\mathrm{Hg}$ methylation occurs both in coastal and shelf sediments, and in sub-thermocline low-oxygen oceanic waters, at depths where organic matter is intensively remineralized (Mason et al., 1995; Fitzgerald et al., 2007; Blum et al., 2013; Cossa et al., 2017). In its methylated forms, $\mathrm{Hg}$ passes through biological membranes easily and is incorporated into cellular cytoplasm (e.g., in phytoplankton), from which it is assimilated very efficiently by higher trophic levels (Le Faucheur et al., 2014). Once incorporated in organisms, Hg strongly binds with protein sulfhydryl groups (-SH). Due this affinity, the elimination or the excretion of the bioaccumulated $\mathrm{Hg}$ is very slow over time, sometimes equal to zero, like in the muscle tissues (Wang and Wong, 2003; Maulvault et al., 2016). As a consequence, Hg has been widely documented to bioaccumulate with size or age in marine organisms (e.g., Monteiro and Lopes, 1990; Cossa et al., 2012; Chouvelon et al., 2014a).

Several factors linked to $\mathrm{Hg}$ marine biogeochemical cycling and its chemical properties are known to influence $\mathrm{Hg}$ bioaccumulation in marine fauna. The concentrations of dissolved $\mathrm{Me}-\mathrm{Hg}$ in ambient waters or in the different habitats of species is a first factor. As an example, mesopelagic species were shown to present higher $\mathrm{Hg}$ concentrations than epipelagic ones (Monteiro et al., 1996; Choy et al, 2009; Chouvelon et al., 2012), due to the probably higher exposition of mesopelagic organisms to Me$\mathrm{Hg}$ in these deep-pelagic layers of organic matter remineralisation (e.g., Cossa et al., 2009; 95 Heimbürger et al., 2010). Time of exposure to $\mathrm{Hg}$ is a second factor that directly influences its 96 bioaccumulation. It is generally inferred by the size or the age of the organisms considered, and usually higher $\mathrm{Hg}$ concentrations are measured in older organisms (due to low elimination rates; see above). The trophic status and/or trophic functioning of ecosystems is a third factor that may be put forward to explain different bioaccumulation rates (e.g., Chen and Folt, 2005). This "trophic factor" 
itself includes several aspects, some being intimately linked to the first two described above. The first

101 aspect of this trophic factor directly concerns system productivity, through the "bio-dilution effect"

102 (Pickhardt et al., 2002). The bio-dilution effect suggests lower Hg bioaccumulation at all trophic levels

103 in mesotrophic areas compared to oligotrophic areas (Harmelin-Vivien et al., 2009; Cresson et al

104 2014a). It is due to the higher number and higher surface area/volume ratio (i.e. size) of cells at the 105 base of mesotrophic systems. This configuration is less favourable to an efficient uptake of $\mathrm{Hg}$ by cells, whose the lower Hg burden (in comparison with cells in oligotrophic area) is then transferred to consumers. Moreover in oligotrophic areas, where cells are thus less abundant and potentially contain

108 higher $\mathrm{Hg}$ burden, primary consumers probably consume virtually all of them. A second aspect of the 109 trophic factor is directly related to the occurrence of specific planktonic communities at the base of 110 food webs. Indeed, in oligotrophic environments, the higher proportions of slowly sinking pico- and 111 nanophytoplanctonic cells that are readily degraded by bacteria within the water column promote Me$112 \mathrm{Hg}$ formation in the heterotrophic active layers of organic matter remineralisation (e.g., Cossa et al., 113 2009; Heimbürger et al., 2010). This aspect is thus intimately derived from the first factor concerning 114 the level of bioavailable $\mathrm{Hg}$ in ambient waters. A third aspect of the trophic factor concerns the 115 "trophic chain length", also corresponding to the number of "nodes" between the considered organisms 116 and the primary producers. The trophic chains are sometimes considered to be longer in less 117 productive environments (i.e. due to the higher recycling of organic matter and bacterial activity; e.g., 118 Biddanda et al., 2001). In the case of biomagnifying contaminants such as $\mathrm{Hg}$, it may therefore lead to 119 higher $\mathrm{Hg}$ concentrations measured in apex predators of oligotrophic systems. Finally, we may 120 hypothesize that the trophic status and associated primary productivity of marine systems influence the 121 growth rate of organisms as well (i.e. lower grow rates in less productive or oligotrophic environments 122 may be expected), hence also influencing the rate of $\mathrm{Hg}$ bioaccumulation (e.g., Simoneau et al., 2005; 123 Trudel and Rasmussen, 2006; Ward et al., 2010).

124 Following these three fundamental factors (i.e. environmental concentrations of $\mathrm{Me}-\mathrm{Hg}$ in ambient 125 waters; age or growth rate of the organisms considered in the different systems; trophic status of 126 systems), which can be related to each other, the bioaccumulation and the biomagnification of $\mathrm{Hg}$ 127 were proved to vary sometimes greatly between marine ecosystems (e.g., Harmelin-Vivien et al., 128 2009; Cossa et al., 2012), or even between environments of a same marine ecosystem (e.g., between 129 epipelagic and mesopelagic environments ; Choy et al., 2009; Chouvelon et al., 2012; Cresson et al., 130 2014a). For instance, the Mediterranean Sea was found to be a peculiar marine ecosystem, 131 characterized by several factors favourable to $\mathrm{Hg}$ contamination yielding to the so-called "Mediterranean Hg anomaly", whereby organisms' Hg concentrations reported are often higher in this 133 sea than in others while seawater concentrations are comparable (Cossa and Coquery, 2005; Harmelin134 Vivien et al. 2009; Cossa et al. 2012). However, relatively few ecosystem-comparative or meta135 analysis studies exist for assessing the relative influence of the different factors described above (e.g, 136 Lavoie et al., 2013), and the probable primary role of oligotrophy on Hg bioaccumulation; especially 
considering offshore species (i.e. expected to be more affected by oligotrophic conditions than neritic

138 species in any system), and/or considering several species at a time (and not only a single species).

139 Moreover, lake ecosystems are more documented (e.g., Chen and Folt, 2005; Kidd et al., 2012; Lavoie

140 et al., 2013) than the marine environment (but see Harmelin-Vivien et al., 2009; Cossa et al., 2012).

141 Finally, the reasons for among-systems differences in $\mathrm{Hg}$ bioaccumulation and biomagnification have 142 been recently described as being yet not well understood, especially those relative to ecosystems' 143 characteristics (Kidd et al., 2012; Lavoie et al., 2013).

144 In this context, the general objective of this study was to compare and evaluate the influence of the 145 trophic status fo systems and of biological processes (i.e. over geochemical ones; e.g., Cossa and 146 Coquery, 2005) on $\mathrm{Hg}$ bioaccumulation and biomagnification in offshore species and food webs from 147 the Bay of Biscay (BoB) in the north-eastern (NE) Atlantic, and from the Gulf of Lions (GoL) in the 148 north-western (NW) Mediterranean. The species included benthopelagic crustaceans and fish (both 149 teleost and cartilaginous) that are characteristic of the shelf-edge in both ecosystems. They were selected to avoid potential bias linked to direct water-discharge inputs of $\mathrm{Hg}$ and/or coastal processes on $\mathrm{Hg}$ cycling and bioaccumulation. Besides, the BoB in the NE Atlantic and the GoL in the NW Mediterranean represent good candidates for such comparative study, firstly due their expected difference in terms of trophic status, even offshore (one being open onto the Ocean, the other being a semi-enclosed Sea). Indeed, the NE Atlantic shelves (such as the Bay of Biscay) and the Mediterranean Sea are considered distinct biogeochemical provinces for a long time (e.g., Longhurst, 1998, 2007; Reygondeau et al., 2013). Moreover, the more oligotrophic character of the Mediterranean system compared to the Atlantic one has been previously documented, especially from the composition of the organic matter (e.g., presence of diazotrophic organisms) sustaining food webs (Kerhervé et al., 2001; Liénart et al., 2017). Nonetheless, a number of species can be found in both ecosystems, allowing direct comparisons. Finally, both areas are major areas for fisheries (for which

$161 \mathrm{Hg}$ bioaccumulation in commercial species may be of concern), and they constitute two out the three 162 French façades considered and monitored by the European Marine Strategy Framework Directive.

163 To fulfil its general objective, this ecosystem-comparative study used comparable and analytically 164 coherent data on total $\mathrm{Hg}(\mathrm{T}-\mathrm{Hg})$ concentrations and carbon (C) and nitrogen (N) stable isotope ratios 165 (as markers of food sources, trophic positions, and ecosystems' properties in terms of trophic status) 166 analysed on the selected species, as described separately by Chouvelon et al. (2012) for the BoB and 167 by Cresson et al. (2014b) for the GoL. In addition, for the present study, analyses of Me-Hg were performed on the samples, to investigate whether the percentage of Me-Hg measured in the selected species may differ between systems. Indeed, while Me-Hg represents the bioaccumulated form of $\mathrm{Hg}$, it is rarely measured and is often considered to be nearly equal to $100 \%$ of total $\mathrm{Hg}(\mathrm{T}-\mathrm{Hg})$, although

171 this can vary between taxa and species (Bustamante et al., 2006; Kehrig et al., 2010; Cossa et al., 172 2012; Briant et al., 2017). Finally, the present additional analysis of Me-Hg allowed comparing the 173 biomagnification rates of $\mathrm{T}-\mathrm{Hg}$ and $\mathrm{Me}-\mathrm{Hg}$ within each system, and between the two contrasted 
174 systems for each $\mathrm{Hg}$ form. Overall, we hypothesized that the trophic status and especially the 175 oligotrophic character of Mediterranean waters should strongly influence the bioaccumulation and/or 176 biomagnification of $\mathrm{Hg}$ observed in medium- to high-trophic level consumers, due to the lower 177 productivity and consequently the lower growth rate and lower "bio-dilution effect" most probably 178 generated at all trophic levels in oligotrophic systems.

\section{Material and Methods}

\subsection{Sampling and sample preparation}

The offshore (shelf-edge) benthopelagic species considered in this study included the lesser-spotted dogfish Scyliorhinus canicula and the blackmouth catshark Galeus melastomus as cartilaginous fish; the blackbelly rosefish Helicolenus dactylopterus, the four-spot megrim Lepidorhombus boscii, the greater forkbeard Phycis blennoides and the blue whiting Micromesistius poutassou as teleost fish; and finally the Norway lobster Nephrops norvegica as crustacean (Table 1). Organisms were collected during bottom-trawling groundfish surveys conducted by the French Institute for the Exploitation of the Sea (IFREMER), in 2008 for the BoB and in 2012 for the GoL (Fig. 1; Chouvelon et al., 2012; Cresson et al., 2014b).

After collection ( $\mathrm{N}=134$ fishes in total considered in the present meta-analysis and comparative study), each individual was measured (total length for fish, cephalothorax length for crustaceans), at least to nearest centimetre for fish or millimetre for crustaceans. A piece of white muscle (without skin nor carapace) was taken for both $\mathrm{Hg}$ analyses and $\mathrm{C}$ and $\mathrm{N}$ stable isotope analysis (SIA), performed individually. All muscle samples were finally frozen at $-20^{\circ} \mathrm{C}$, freeze-dried and ground into a fine powder until further chemical analyses (Chouvelon et al., 2012; Cresson et al., 2014b).

The determination of the age of organisms could not be performed due to non-uniform sampling of otoliths for age lecture, although in any case, this age determination would have been only potentially possible for teleost fish (that is, for four of the seven species considered here), if the otolith sampling had been done uniformly. Thus, in the present study, only the individual sizes were used as an indicator of the time of exposure to contaminant (i.e. as a proxy of organisms' age within a species), and/or related to potential differences in the growth rate of all organisms between systems.

\subsection{Stable isotope analyses}

Muscle sub-samples for SIA $(\mathrm{N}=134)$ were prepared as described by Chouvelon et al. (2012) and Cresson et al. (2014b). $0.40 \pm 0.05 \mathrm{mg}$ of powder were finally weighed in tin cups. Analyses were performed with a Thermo Scientific Delta V Advantage mass spectrometer coupled to a Thermo Scientific Flash EA1112 elemental analyser. The results are presented in the usual $\delta$ notation relative 
to the deviation from international standards (Pee Dee Belemnite for $\delta^{13} \mathrm{C}$ values, and atmospheric

208 nitrogen for $\delta^{15} \mathrm{~N}$ values), in parts per thousand (\%). Based on replicate measurements of internal 209 laboratory standards (acetanilide), the experimental precision was $<0.2 \%$ for both $\delta^{13} \mathrm{C}$ and $\delta^{15} \mathrm{~N}$. 210 Moreover, a previous study using the same instruments as in the present study indicated no statistically 211 significant difference for both $\delta^{13} \mathrm{C}$ and $\delta^{15} \mathrm{~N}$ on duplicate measurements of a same sample (Chouvelon 212 et al., 2014b), indicating highly reliable and precise values for the unique analysis of well213 homogenised material such as the muscle samples used here.

\subsection{Total and methyl-Hg analyses}

215 As in the case of SIA, muscle sub-samples for $\mathrm{T}-\mathrm{Hg}$ determination $(\mathrm{N}=134)$ were prepared and analysed as described by Chouvelon et al. (2012) and Cresson et al. (2014b). T-Hg analyses were carried out on aliquots of powder (10-50 mg) with Advanced Mercury Analysers (ALTEC AMA-254, Altec Ltd). Through this mean, the determination of $\mathrm{Hg}$ is done in three steps: (1) combustion of the dedicated sub-sample (dried powder) and volatilization of $\mathrm{Hg}$; (2) amalgamation of elemental $\mathrm{Hg}$ on a gold trap; and (3) spectrophotometric atomic absorption measurement of the Hg swept into the flow cell following heating $\left(800^{\circ} \mathrm{C}\right)$ of the gold trap. All T-Hg analyses were run according to thorough quality control programmes including the analysis of certified reference materials (CRMs): TORT-2 (lobster hepatopancreas, National Research Council Canada/NRCC), IAEA-142 (mussel homogenate,

224 International Atomic Energy Agency/IAEA), DORM-2 and/or DORM-4 (fish protein, NRCC). CRM results were in good agreement with the certified values in all cases, with recovery rates varying between 95\% and 102\% (Chouvelon et al., 2012; Cresson et al., 2014b). The limit of quantification was $\leq 0.02 \mu \mathrm{g} \mathrm{g}^{-1}$ dry mass $(\mathrm{dm})$.

228 Me-Hg determination was performed on a subsample of individuals $(n=75)$ according to the method 229 described by Azemard and Vassileva (2015), which uses liquid-liquid extractions of Me-Hg in 230 samples before analysis by automated $\mathrm{Hg}$ analysers such as AMA-254. Briefly, aliquots of powder 231 (20-800 mg, depending on T-Hg concentrations) were acidified with $5 \mathrm{~mL}$ of $\mathrm{HCl}(25 \%$, v/v, prepared 232 with HCL $30 \%$ Suprapur) to solubilize $\mathrm{Hg}$. A volume of toluene (10 mL) was added and both phases 233 were homogenized. After centrifugation, a fraction $(5 \mathrm{~mL})$ of the upper organic phase (i.e. toluene 234 containing extracted $\mathrm{Me}-\mathrm{Hg}$ ) was transferred to a second tube containing the same volume of a $2350.002 \mathrm{M}$ sodium thiosulfate solution. This second tube was vigorously shaken and centrifuged. Finally, an aliquot of a known volume (100 or $200 \mu \mathrm{L})$ of the lower phase, containing the back-extracted Me$237 \mathrm{Hg}$, was directly analysed with AMA 254. As for $\mathrm{T}-\mathrm{Hg}$ determination, Me- $\mathrm{Hg}$ analyses were run 238 according to a thorough quality control programme including the analysis of the CRM IAEA-436 239 (tuna fish flesh homogenate). The average recovery rates for the CRM varied from 81 to $90 \%$ between 240 the series of analyses (i.e. between the days of analyses), against $92 \%$ on average expected by 241 Azemard and Vassileva (2015) for this CRM. However, within a same series or day of analyses, the 
variation in the recovery rates of CRMs (2 to $3 \mathrm{CRMs}$ analysed at each series/day of Me-Hg analyses)

243 was very low (i.e. average standard deviation of $2 \%$ ). Therefore, the repeatability of the CRM results

244 was ensured within a same series, and $\mathrm{Me}-\mathrm{Hg}$ results for the samples could be corrected from the

245 average recovery rate of the CRMs analysed during the same series/day of analyses. Finally, several

246 samples were analysed twice (in two different series/day of analyses). The mean difference observed

247 between the two measurements, for the calculated percentage of $\mathrm{Me}-\mathrm{Hg}$ relative to T-Hg (i.e. ratio of

$248 \mathrm{Me}-\mathrm{Hg}$ concentration/ $\mathrm{T}-\mathrm{Hg}$ concentration, in \%), was of $4 \pm 2 \%$.

\subsection{Data treatment}

250 All data submitted to statistical tests (and/or model residuals) were checked for normality, and for

251 homogeneity of variances and lack of violation of independence when appropriate (Zuur et al., 2007).

252 For each species considered, differences between systems in individual sizes, $\delta^{13} \mathrm{C}$ and $\delta^{15} \mathrm{~N}$ values, T-

$253 \mathrm{Hg}$ concentrations and percentages of $\mathrm{Me}-\mathrm{Hg}$ were thus tested by the parametric Student $\mathrm{t}$-test or the

254 non-parametric Mann-Whitney-Wilcoxon test, depending on whether the data satisfied the conditions

255 for parametric statistics or not.

256 The correlation between $\mathrm{T}-\mathrm{Hg}$ and $\mathrm{Me}-\mathrm{Hg}$ concentrations (for the subsample of individuals analysed

257 for both parameters) was tested through the non-parametric Spearman correlation coefficient test.

258 The relationship between $\mathrm{T}-\mathrm{Hg}$ or $\mathrm{Me}-\mathrm{Hg}$ concentrations and $\delta^{15} \mathrm{~N}$ values (i.e. as proxy of the 259 individual trophic positions within a given ecosystem) was investigated through Generalized Linear 260 Models (GLMs). Indeed, data showed a marked departure from normality, preventing the application 261 of classical multiple linear regressions. However, thorough data exploration suggested the linearity of 262 trends to be modelled, making the application of Generalized Additive Models - than can capture and 263 model complex non-linear relationships - unnecessary. GLMs were thus fitted to log-transformed $\mathrm{Hg}$ 264 concentrations with an identity link function, as it is generally the case when dealing with contaminant 265 data such as trace metals (e.g., Pierce et al., 2008; Mendez-Fernandez et al., 2013; Chouvelon et al., $2662014 \mathrm{a}, 2017)$. This allowed estimating the effect of $\delta^{15} \mathrm{~N}$ values in explaining $\mathrm{Hg}$ concentration 267 variability. Moreover, such relationships allowed the biomagnification power (BP) of T-Hg and Me-

$268 \mathrm{Hg}$ to be determined and to be compared between ecosystems (Chen et al., 2008; Borgå et al., 2012; 269 Lavoie et al., 2013). $\delta^{15} \mathrm{~N}$ values were treated as the single continuous explanatory variable in the 270 models, while the factor "Ecosystem" was treated as a categorical explanatory variable and added as a 271 potential interaction term. The general form of the original models performed was:

$272 \log _{10}[\mathrm{~T}-\mathrm{Hg}]$ or $\log _{10}[\mathrm{Me}-\mathrm{Hg}] \sim \delta^{15} \mathrm{~N}+$ Ecosystem [+ interaction term $\delta^{15} \mathrm{~N}$ :Ecosystem].

273 Results (fitted values) of the models were plotted on observed (log-transformed) data. Final models' 274 parameters (estimates, p-values, etc.) and details on their interpretation are given in Table 2. For each 275 model, we retained the variables that improved the relative goodness of fit in the GLMs (i.e. most 276 parsimonious models) based on the Akaike Information Criterion (AIC). When the AIC was not 
significantly different between the last two nested models, the simplest model was preferred. Finally, a model validation was systematically applied (Zuur et al., 2007), and the percentage of total deviance explained (DE) was calculated as follows: Explained deviance $=(($ Null model deviance - final model residual deviance)/Null model deviance)*100, with the null model that only contained the intercept terms (Mendez-Fernandez et al., 2013; Chouvelon et al., 2017). The same type of models (GLMs) was finally applied to test potential significant difference in the slope of the relationships (i.e. in the BP) between T-Hg and Me-Hg (i.e. between the different forms of $\mathrm{Hg}$ ) within each system. $\delta^{15} \mathrm{~N}$ values were treated as the single continuous explanatory variable in the models, while the factor "Hg form" was treated as a categorical explanatory variable and added as a potential interaction term. The general form of the original models performed was: $\log _{10}[\mathrm{Hg}]$ in the $\mathrm{BoB}$ or in the $\mathrm{GoL} \sim \delta^{15} \mathrm{~N}+\mathrm{Hg}$ form [+ interaction term $\delta^{15} \mathrm{~N}: \mathrm{Hg}$ form]. The level of significance for statistical analyses was always set at $\alpha=0.05$.

\section{Results}

In both systems, species-dependent patterns in $\mathrm{Hg}$ concentrations (either $\mathrm{T}-\mathrm{Hg}$ or $\mathrm{Me}-\mathrm{Hg}$ ) were similar, with the two shark species S. canicula and G. melastomus and the teleost fish H. dactylopterus presenting the highest $\mathrm{Hg}$ concentrations, the two teleost fish P. blennoides and L. boscii presenting intermediate concentrations, and the teleost fish $M$. poutassou and the crustacean $N$. norvegica presenting the lowest $\mathrm{Hg}$ concentrations (Table 1).

296 Mediterranean individuals had significantly lower sizes than those from the NE Atlantic (BoB) for five out of the seven species considered (Table 1, Fig. 2a), along with significantly higher T-Hg concentrations for all species except L. boscii (Table 1, Fig. 2b). However, although non significant for L. boscii, higher average values were found in Mediterranean individuals of this species as well (Table 1). Concomitantly, for all species considered, significantly lower $\delta^{13} \mathrm{C}$ and $\delta^{15} \mathrm{~N}$ values were measured in Mediterranean organisms relative to Atlantic ones (Table 1, Fig. 2c).

$302 \mathrm{Me}-\mathrm{Hg}$ concentrations were strongly correlated with $\mathrm{T}-\mathrm{Hg}$ concentrations (Fig. 3), and the average 303 percentage of $\mathrm{Me}-\mathrm{Hg}$ (relative to $\mathrm{T}-\mathrm{Hg}$ ) was over $85 \%$ for all the considered species and in both 304 systems (Table 1, Fig. 2d). This percentage of Me-Hg was significantly higher in Atlantic individuals relative to Mediterranean ones for only three out of the seven species considered (i.e. for H. dactylopterus, P. blennoides and M. poutassou), although slightly, and the difference was not significant for the four other species (Fig. 2d). Moreover, the standard deviations around average Me$\mathrm{Hg} / \mathrm{T}-\mathrm{Hg}$ ratios were quite high (Table 1), and the recovery of values between individuals from the different systems was quite important (Fig. 2d).

310 The effect of $\delta^{15} \mathrm{~N}$ values for explaining T-Hg or Me-Hg concentrations' variability was significant in 311 all cases (i.e. significant relationships between parameters), as well as the factor "Ecosystem" (i.e. 
significant difference between Atlantic and Mediterranean). The intercept was systematically higher

313 for Mediterranean organisms than for Atlantic ones in all relationships (Table 2, Fig. 4). For Me-Hg,

314 contrary to $\mathrm{T}-\mathrm{Hg}$, the interaction term was not significant. As such, the model predicted similar

315 slope/similar BP for Me-Hg in both ecosystems, at least at the scale of the species and food webs

316 considered in the present study. Finally, when considering each system separately, the difference of

317 slope/of BP between T-Hg and Me-Hg was not significant (i.e. no effect of the factor "Hg form" on

318 the relationships with $\delta^{15} \mathrm{~N}$ values within each system), probably due to the high correlation between

319 T-Hg and Me-Hg concentrations (Fig. 3).

\section{Discussion}

\subsection{General trends and differences between systems}

322 Results clearly showed a significantly higher $\mathrm{Hg}$ bioaccumulation by Mediterranean organisms, along 323 with significantly lower $\mathrm{C}$ and $\mathrm{N}$ stable isotope ratios measured for all species, and lower individual 324 sizes for most of them. Conversely, the percentage of $\mathrm{MeHg}$ was similar between both systems for 325 most of the species examined, although significantly slightly higher in Atlantic organisms than in 326 Mediterranean ones for some species. When considering Me-Hg, the BP was not significantly different 327 between systems, but was significantly higher in the Atlantic food web than in the Mediterranean one when considering T-Hg. Besides, within each system, T-Hg and Me-Hg BPs appeared to not differ significantly.

330 Firstly, in terms of T-Hg concentrations, the species-dependent pattern observed was similar between

331 systems. Moreover, it was consistent with the general diet and ecology documented for the considered 332 species (www.sealifebase.org and associated references) and with the well-documented biomagnifying 333 property of $\mathrm{Hg}$ in food webs (Boening, 2000). Indeed, the two shark species S. canicula and 334 G. melastomus and the teleost fish H.dactylopterus (i.e. species presenting the highest $\mathrm{Hg}$ 335 concentrations) are considered high-trophic level consumers mainly feeding on a wide variety of prey, 336 including both benthic and pelagic fish, cephalopods and crustaceans. Compared with the others, these three species are also morphologically able to capture relatively large prey (i.e. of potentially high trophic level as well). Alternatively, P. blennoides is documented to feed mostly on crustacean and fish prey, and L. boscii on small bottom-living crustaceans, fish and squids. The diet of the individuals of M. poutassou corresponding to the sizes sampled here is mainly composed of small crustaceans such as zooplankton. Finally, the crustacean $N$. norvegica is considered mainly scavenger, feeding on

342 detritus, benthic crustaceans and worms (www.sealifebase.org and associated references).

343 Secondly, the different parameters considered in this ecosystem-comparative study (i.e. sizes of the 344 organisms compared, $\delta^{13} \mathrm{C}$ and $\delta^{15} \mathrm{~N}$ values, $\mathrm{T}-\mathrm{Hg}$ and Me-Hg concentrations) showed the crucial role of the trophic status at the base of systems - especially oligotrophy - in the trophic transfer and in the 
bioaccumulation of $\mathrm{Hg}$ by high-trophic level consumers. Similarly to our study, higher concentrations in Mediterranean organisms than in their counterparts in the Atlantic were recently described for the neritic food web of the European hake Merluccicus merluccius between the GoL and the BoB (Cossa et al., 2012), being coherent with the "Mediterranean $\mathrm{Hg}$ anomaly" (i.e. higher $\mathrm{Hg}$ bioaccumulation observed in organisms from this system relative to other systems, despite comparable concentrations in seawaters from both areas; Aston and Fowler, 1985; Cossa and Coquery, 2005). However, to the best of our knowledge, such comparison of systems as done in the present study was relatively rarely performed, especially on several medium- to high-trophic level species at a time, and on offshore species, which are potentially submitted to oligotrophic conditions - at least in part - in both systems (compared to neritic species).

The $\mathrm{C}$ and $\mathrm{N}$ stable isotope compositions (especially $\delta^{15} \mathrm{~N}$ values) of the species examined, although characteristic offshore species of the shelf-edge in both systems, revealed the significant differences between the two systems in terms of trophic status and consequently in terms of sources of organic matter and primary producers sustaining the respective food webs. Unfortunately, no dedicated sampling of plankton could be carried out for the present study to get the $\delta^{15} \mathrm{~N}$ values (and $\mathrm{Hg}$ concentrations) of the planktonic compartment, which could be directly related to those of the medium to high-trophic level consumers here of concern. However, the $\delta^{15} \mathrm{~N}$ values of the consumers considered here clearly showed the more oligotrophic character of the Mediterranean waters in general. Indeed, the fixation of atmospheric $\mathrm{N}_{2}$ by diazotrophic organisms (e.g., cyanobacteria) in offshore and oligotrophic waters is well documented to lower the $\delta^{15} \mathrm{~N}$ values of the residual $\mathrm{NO}_{3}{ }^{-}$pool available for primary producers in these areas (see review by Montoya, 2007). Diazotrophic organisms were demonstrated to be preponderant in the GoL (Kerhervé et al., 2001; Le Moal and Biegala, 2009; Liénart et al., 2017), thus resulting in low $\delta^{15} \mathrm{~N}$ values in consumers at all trophic levels (especially when compared to their counterparts in the $\mathrm{BoB}$ waters, for instance), from mesozooplankton (Chouvelon et al., 2012, 2014b; Espinasse et al., 2014; Bănaru et al., 2014) and suspension-feeders like bivalves (Cresson et al., 2016; Briant et al., 2018) to deep-sea fish and crustaceans (present study; Cresson et al., 2014b). Finally, the results of the present study highlighted the higher primary productivity of the BoB offshore waters (i.e. higher $\delta^{15} \mathrm{~N}$ values measured in individuals from this ecosystem) compared to offshore GoL waters. In the BoB, in the Cap-Ferret canyon's head area (i.e. offshore area) for instance, the annual primary productivity was effectively estimated to be $145-170$ $\mathrm{gC} / \mathrm{m}^{2}$ (Laborde et al., 1999), while it was estimated to be $78-142 \mathrm{gC} / \mathrm{m}^{2}$ in the GoL (Lefevre et al., 1997).

378 The significant difference of sizes observed for most of the species considered here, despite comparable sampling methodology and effort, were also indicative of a difference in individual size distribution between the two systems with contrasted trophic status. This difference is likely due to the lower growth rate of Mediterranean organisms compared their Atlantic counterparts, like observed for the hake M. merluccius, for instance (De Pontual et al., 2006 and Mellon-Duval et al., 2009). As such, 
383 for similar-sized individuals, organisms from the Mediterranean are surely much older than their

384 Atlantic counterparts. In the previous study by Cossa et al. (2012), this partly explained the higher 385 concentrations of $\mathrm{Hg}$ observed in Mediterranean hakes compared to Atlantic ones due to age-related 386 bioaccumulation of the metal, in addition to the fact that $\mathrm{Hg}$ burden is also more bio-diluted in larger 387 organisms.

\subsection{Me-Hg/T-Hg ratios, bioaccumulation and biomagnification of $\mathrm{Hg}$}

389 The relatively high percentage of Me-Hg measured (i.e. $>85 \%$ on average for all species and in both 390 ecosystems) was expected, since muscle was the tissue examined, and since the trophic position of the 391 species considered was quite elevated. Indeed, this percentage has long been considered virtually equal 392 to $100 \%$ in the muscle of high-trophic level consumers such as fish and cephalopod molluscs (e.g., 393 Bloom, 1992), due to the high affinity of Hg for muscular proteins' sulfhydryl groups, although it generally varies between 60 and 90\% depending on species and on their trophic level (e.g., 395 Bustamante et al., 2006; Kehrig et al., 2010; Cossa et al., 2012). It may be also elevated in some 396 crustacean species, but it is clearly lower (generally largely $<50 \%$ ) in low-trophic level consumers 397 such as bivalve molluscs (e.g., Cossa et al., 2012; Briant et al., 2017). Opposite to the other parameters 398 regarded (i.e. individual sizes, $\delta^{13} \mathrm{C}$ and $\delta^{15} \mathrm{~N}$ values, raw $\mathrm{T}-\mathrm{Hg}$ and $\mathrm{Me}-\mathrm{Hg}$ concentrations), the 399 percentage of Me-Hg in the muscle of the selected organisms generally did not differ a lot between the $400 \mathrm{BoB}$ and the GoL organisms. These results are in agreement with those of Cossa et al. (2012) that 401 observed no significant differences in the percentage of Me-Hg in Mediterranean vs. Atlantic hakes. 402 The fact that only medium- to high-trophic levels were considered here may partly explain this 403 absence of difference in the $\mathrm{Me}-\mathrm{Hg} / \mathrm{T}-\mathrm{Hg}$ ratios between organisms from the two systems. Indeed, 404 when considering organisms at the top of food webs, potential differences that could exist in the Me$405 \mathrm{Hg} / \mathrm{T}-\mathrm{Hg}$ proportions at the basal levels (in seawater, and/or in low-trophic level organisms) may no 406 longer be visible.

407 In fact, water Me-Hg concentrations were shown to be comparable between the BoB and the GoL 408 shelf-edge ecosystems (Cossa et al., 2012). However, the BoB has probably a deeper thermohalocline 409 than the GoL and consequently a deeper organic matter regeneration zone, where $\mathrm{Hg}$ is likely 410 methylated (Heimbürger et al., 2010; Blum et al., 2013; Cossa et al., 2017). As the species considered 411 here are endemic of the shelf-edge and heads of canyons, they may be therefore more exposed to Me$412 \mathrm{Hg}$ in Mediterranean waters than in Atlantic ones (through the higher content of Me-Hg in the lower 413 trophic levels themselves). This hypothesis is also supported by the lower percentage of Me-Hg 414 measured for M. poutassou in the GoL in particular, relative to the other fish species examined. 415 Indeed, the shallower foraging zone of this species was previously proposed as an explanation of its 416 lower T-Hg burdens (Cresson et al. 2014b), but this may also explain the lower proportion of Me-Hg 417 in the muscle of this species, in addition to its lower trophic level in comparison with other species. 
418 The significant relationships between log-transformed $\mathrm{Hg}$ concentrations and $\delta^{15} \mathrm{~N}$ values were in 419 agreement with the species-dependent patterns previously observed (i.e. increasing concentrations 420 with increasing trophic levels), and were thus also consistent with the well-documented property of $\mathrm{Hg}$ 421 to biomagnify in food webs (Boening, 2000). Furthermore, the equations of these relationships allow 422 to compare the BP of this metal across food webs, using the slope of the relationships as a measure of 423 the biomagnification rate, and the intercept as the baseline value for primary producers in the different 424 systems (Chen et al., 2008; Cossa et al., 2012; Lavoie et al., 2013). Then, the biomagnification power 425 (BP) of $\mathrm{Hg}$ may be expected to differ between systems when the $\delta^{15} \mathrm{~N}$ values of plankton (i.e. low 426 trophic levels) differ between systems, and/or when $\mathrm{Hg}$ concentrations in plankton differ between 427 systems. Besides, variations in the $\delta^{15} \mathrm{~N}$ values or $\mathrm{Hg}$ concentrations of plankton are linked, at least 428 part, to the composition of plankton (some planktonic species being able to fix atmospheric nitrogen 429 with peculiar N signature, for instance; Kerhervé et al., 2001). As a consequence, the BP may be 430 expected to differ between systems with different trophic status, i.e. between systems with different 431 planktonic communities at the base of food webs.

432 Here, higher intercepts were found for the Mediterranean ecosystem, indicating a probably higher $\mathrm{Hg}$ 433 burden from the lowest trophic levels in the GoL compared to BoB (i.e. lower "bio-dilution" effect in 434 the GoL's low trophic levels than in those from the BoB). However, the intercept is intimately linked 435 to the slope, and such direct link with $\mathrm{Hg}$ baseline values should be done with caution when the lowest 436 trophic levels (plankton) are not available (Borgå et al., 2012), as it is the case for the present study. 437 Biomagnification slopes (i.e. BPs), were previously reported to range between 0.09 and 0.22 for $\mathrm{T}-\mathrm{Hg}$ 438 (average $0.20 \pm 0.10$ ) and between 0.14 and 0.26 for $\mathrm{Me}-\mathrm{Hg}$ (average $0.22 \pm 0.09$ ) in marine 439 ecosystems (Lavoie et al., 2013). When considering Me-Hg concentrations, the BPs measured here 440 (0.21 for both BoB and GoL ecosystems, not significantly different) are therefore within this range of 441 values. Alternatively, when calculated from $\mathrm{T}-\mathrm{Hg}$ concentrations, the BPs significantly differed 442 between the BoB (0.35) and the GoL (0.11), with a lower BP estimated for the Mediterranean system. 443 This differs from the results of Cossa et al. (2012), for instance, which found a higher BP in the hake 444 food web from the GoL (Mediterranean) than in those from the BoB (Atlantic). The consideration of 445 different food webs and organisms may be at the origin of the discrepancy between our study and 446 those of Cossa et al. (2012) (i.e. consideration of the neritic hake food web by Cossa et al., 2012, 447 including lower trophic levels, vs. shelf-edge/offshore organisms and medium- to high-trophic levels 448 only here). Moreover, the lower BP found here for the Mediterranean ecosystem may favour the 449 hypothesis of potentially higher basal $\mathrm{Hg}$ levels (i.e. in plankton) than in Atlantic for the shelf-edge 450 food webs considered here (as suggested by the different intercept as well), although the 451 biomagnification potential of $\mathrm{Hg}$ may be then not especially higher in the rest of the food web (as 452 suggested by similar BPs when considering the bioavailable and bioaccumulable form Me-Hg). 453 Finally, if our estimated BPs probably remain comparable at the scale of our study between GoL and $454 \mathrm{BoB}$, with the same species considered in both systems, they are not necessarily comparable to other 
studies that would include other (non-fish) species and especially lower trophic levels (e.g., Signa et

456 al., 2017).

457 Overall, the present study thus showed that the higher $\mathrm{Hg}$ bioaccumulation rate by Mediterranean

458 organisms is likely linked to the oligotrophic character of waters and associated lower productivity in 459 this system. Indeed, compared to mesotrophic environments, oligotrophic conditions are likely 460 associated with: i) increased formation of the bioavailable $\mathrm{Me}-\mathrm{Hg}$ at the depths of organic matter 461 regeneration (i.e. where the shelf-edge/offshore species considered here likely live), due to greater 462 proportions of slowly sinking pico- and nanophytoplanctonic cells that are readily degraded by 463 bacteria there (Cossa et al., 2009; Heimbürger et al., 2010); ii) lower bio-dilution of $\mathrm{Hg}$ from the lower 464 trophic levels (i.e. phytoplankton; Pickhardt et al., 2002), with the presence of smaller and less 465 abundant cells that are then also much more consumed - including their high $\mathrm{Hg}$ burden - by higher 466 trophic level organisms; iii) lower growth rate of consumer organisms and consequently, lower bio467 dilution of $\mathrm{Hg}$ burden in their tissues as well and high $\mathrm{Hg}$ retention with the age of organisms, the 468 elimination rate of the bioaccumulated Hg being very low (Wang and Wong, 2003; Maulvault et al., 469 2016).

470 Finally, the potential impact of temperature differences between $\mathrm{GoL}$ and $\mathrm{BoB}$ on $\mathrm{Hg}$ bioaccumulation 471 is also interesting to address in the context of global change. Higher temperatures are likely to enhance 472 bacterial activity and consequently Me-Hg formation, which in our study case may also partly explain 473 the higher $\mathrm{Hg}$ bioaccumulation observed in Mediterranean organisms. Indeed in the GoL, the sea 474 surface temperatures were shown to vary between 14 and $20^{\circ} \mathrm{C}$ and to remain relatively constant 475 around $13{ }^{\circ} \mathrm{C}$ below 100-200 m depth (Conan et al. 1998), while in the BoB, the sea surface 476 temperatures are slightly colder. They vary between 11 and $20^{\circ} \mathrm{C}$ (for the southern part, less in the 477 northern one) and remain below $12{ }^{\circ} \mathrm{C}$ in depth (Koutsikopoulos and Le Cann, 1996). In addition, 478 higher temperatures such as it is likely the case for Mediterranean waters were proved to promote Me$479 \mathrm{Hg}$ bioaccumulation and to hamper its elimination in fish tissues, for instance (Maulvault et al., 2016), 480 which is also in favour of higher potential for $\mathrm{Hg}$ bioaccumulation in Mediterranean organisms.

\section{Conclusion and perspectives}

483 The effect of ecosystems' characteristics on Hg bioaccumulation and biomagnification was already 484 demonstrated in freshwater ecosystems (e.g., lakes) through comparative studies (e.g., Kidd et al., 485 2012). Such ecosystem-comparative or meta-analysis studies remained rare for marine ecosystems.

486 They were therefore recently encouraged to be done for generating new testable hypotheses 487 concerning Hg bioaccumulation and biomagnification (Lavoie et al., 2013).

488 Benefiting from archived samples from the GoL and the BoB shelf-edge/offshore ecosystems, our 489 study showed the strong influence of the trophic status and/or functioning of systems on $\mathrm{Hg}$ 
bioaccumulation in marine medium- to high-trophic level organisms, which are generally important commercial species. It also reinforced and confirmed the hypothesis made by Cossa and Coquery (2005) that biological processes dominate the geochemical ones in explaining the "Mediterranean mercury anomaly". Furthering some previous studies focusing on the coastal or neritic species that are red mullets or hakes (Cossa et al., 2012; Cresson et al., 2014a; 2015), the present marine ecosystemcomparative study demonstrated the crucial role of oligotrophy and associated lower productivity on $\mathrm{Hg}$ bioaccumulation, at both multi-species and multi-systems scales.

As the processes of bio-dilution and low elimination rates may also apply to other metals, we propose that the bioaccumulation of other metals may be also determined by the trophic status of the considered ecosystems in a non-negligible part. Thus, it would be interesting to examine other trace metals on the samples used in the present study, to investigate whether oligotrophy may also influence their bioavailability, transfer and bioaccumulation, and whether the patterns observed for $\mathrm{Hg}$ are also applicable or not for other trace elements (e.g., species-dependant patterns kept or not between the systems). Also, investigating the potential differences in the energy content of prey species/lower trophic levels between systems (i.e. expected to be affected by oligotrophy in Mediterranean waters, for instance) may be interesting. This would enable to more globally apprehend the mechanisms involved in the transfer of contaminants (especially the lipophilic ones) to higher trophic levels, and their transfer in food webs in general. Finally, with regard to the high significance of the trophic status of systems on $\mathrm{Hg}$ bioaccumulation shown in the present study, further work on very low trophic levels (i.e. plankton) would be also highly relevant.

\section{Acknowledgments}

513 Authors are particularly grateful to the "Agence de l'Eau Rhône Méditerranée Corse" (AERMC) for

514 financial support of the Mediterranean analyses and of the associated RETROMED project, as well as

515 to the "Conseil Régional de Poitou-Charentes" and the "Contrat de projet Etat-Région" (CPER 2013)

516 that supported the analyses relative to the Bay of Biscay area during the $\mathrm{PhD}$ of $\mathrm{T}$. Chouvelon. We are

517 grateful to C. Churlaud from the "Plateforme Analyses Elémentaires" of LIENSs for her assistance

518 during $\mathrm{Hg}$ analyses and to G. Guillou, P. Richard and B. Lebreton from the "Plateforme de 519 Spectrométrie Isotopique" of the LIENSs laboratory for their assistance during SIA analyses. Thanks 520 are also due to M.C. Fabri for its implication in the RETROMED project, and to F. Chavanon and

521 C. Ravel for their help during sampling and laboratory work. Finally, authors want to thank the chief scientists and the crew of the R/V "Thalassa" and "L'Europe" for facilitating the sampling during EVHOE 2008 (http://dx.doi.org/10.17600/8040120) and MEDITS

524 (http://dx.doi.org/10.17600/12060100) surveys. 
Aston SR, Fowler SW (1985). Mercury in the open Mediterranean: evidence of contamination? Sci Total Environ 43: 13-26.

Azemard S, Vassileva E (2015). Determination of methylmercury in marine biota samples with advanced mercury analyser: Method validation. Food Chem 176: 367-375.

Bănaru D, Carlotti F, Barani A, Grégori G, Neffati N, Harmelin-Vivien M (2014). Seasonal variation of stable isotope ratios of size-fractionated zooplankton in the Bay of Marseille (NW Mediterranean Sea). J Plankton Res 36: 145-156.

Biddanda B, Ogdahl M, Cotner J (2001). Dominance of bacterial metabolism in oligotrophic relative to eutrophic waters. Limnol Oceanogr 46: 730-739.

Bloom NS (1992). On the chemical form of mercury in edible fish and marine invertebrate tissue. Can J Fish Aquat Sci 49: 1010-1017.

Blum JD, popp BN, Drazen JC, Choy CA, Johnson MW (2013). Methylmercury production below the mixed layer in the North Pacific Ocean. Nat Geosci 6: 879-884.

Boening D (2000). Ecological effects, transport, and fate of mercury: A general review. Chemosphere 40: $1335-1351$.

Borgå K, Kidd KA, Muir DCG, Berglund O, Conder JM, Gobas FAPC, Kucklick J, Malm O, Powell DE (2012). Trophic magnification factors: considerations of ecology, ecosystems, and study design. Integr Envrion Assess Manag 8: 64-84.

Briant N, Chouvelon T, Martinez L, Brach-Papa C, Chiffoleau JF, Savoye N, Sonke J, Knoery J (2017). Spatial and temporal distribution of mercury and methylmercury in bivalves from the French coastline. Mar Pollut Bull 114: 1096-1102.

Briant N, Savoye N, Chouvelon T, David V, Rodriguez S, Charlier K, Sonke J, Chiffoleau JF, BrachPapa C, Knoery J (2018). Carbon and nitrogen elemental and isotopic ratios of filter-feeding bivalves along the French coasts: An assessment of specific, geographic, seasonal and multidecadal variations. Sci Tot Environ 613-614: 196-207.

Bustamante P, Lahaye V, Durnez C, Churlaud C, Caurant F (2006). Total and organic Hg concentrations in cephalopods from the North Eastern Atlantic waters: influence of geographical origin and feeding ecology. Sci Total Environ 368: 585-596.

Chen C, Amirbahman A, Fisher N, Harding G, Lamborg C, Nacci D, Taylor D (2008). Methylmercury in marine ecosytems: Spatial patterns and processes of production, bioaccumulation, and biomagnification. EcoHealth 5: 399-408.

Chen CY, Folt CL (2005). High plankton densities reduce mercury biomagnification. Environ Sci

561 Chouvelon T, Spitz J, Caurant F, Mèndez-Fernandez P, Autier J, Lassus-Débat A, Bustamante P 562 (2012). Enhanced bioaccumulation of mercury in deep-sea fauna from the Bay of Biscay (North- 
East Atlantic) in relation to trophic positions identified by analysis of carbon and nitrogen stable isotopes. Deep-Sea Res I 65: 113-124.

565 Chouvelon T, Caurant F, Cherel Y, Spitz J, Simon-Bouhet B, Bustamante P (2014a). Species- and size-related patterns in stable isotopes and mercury concentrations in fish help refine marine ecosystem indicators and provide evidence for distinct management units for hake in the Northeast Atlantic. ICES J Mar Sci 75: 1073-1087.

Chouvelon T, Chappuis A, Bustamante P, Lefebvre S, Mornet F, Guillou G, Violamer L, Dupuy C (2014b). Trophic ecology of European sardine Sardina pilchardus and European anchovy Engraulis encrasicolus in the Bay of Biscay (North-East Atlantic) inferred from $\delta^{13} \mathrm{C}$ and $\delta^{15} \mathrm{~N}$ values of fish and identified mesozooplanktonic organisms. J Sea Res 85: 277-291.

Chouvelon T., Brach-Papa C, Auger D, Bodin N, Bruzac S, Crochet S, Degroote M, Hollanda SJ, Hubert C, Knoery J, Munschy C, Puech A, Rozuel E, Thomas B, West W, Bourjea J, Nikolic N (2017). Chemical contaminants (trace metals, persistent organic pollutants) in albacore tuna from western Indian and south-eastern Atlantic Oceans: Trophic influence and potential as tracers of populations. Sci Tot Environ 596-597: 481-495.

Choy CA, Popp BN, Kaneko JJ, Drazen JC (2009). The influence of depth on mercury levels in pelagic fishes and their prey. Proc Natl Acad Sci USA 106: 13865-13869.

Cossa D, Averty B, Pirrone N (2009). The origin of methylmercury in open Mediterranean waters. Limnol Oceanogr 54: 837-844.

Conan P, Pujo-Pay M, Raimbault P, Leveau M (1998). Variabilité hydrologique et biologique du golfe du Lion. II. Productivité sur le bord interne du courant. Oceanol Acta 21: 767-782.

Cossa D, Coquery M (2005). The Mediterranean mercury anomaly, a geochemical or a biological issue. In: Saliot A (ed.), The Mediterranean Sea. Handbook of Environmental Chemistry, v.5. Springer Berlin Heidelberg, pp 177-208.

Cossa D, Harmelin-Vivien M, Mellon-Duval C, Loizeau V, Averty B, Crochet S, Chou L, Cadiou JF (2012). Influences of bioavailability, trophic position, and growth on methylmercury in hakes (Merluccius merluccius) from Northwestern Mediterranean and Northeastern Atlantic. Environ Sci Technol 46: 4885-4893.

Cossa D, Durrieu de Madron Xavier, Schäfer J, Lanceleur L, Guédron S, Buscail R, Thomas B, Castelle S, Naudin JJ (2017). The open sea as the main source of methylmercury in the water column of the Gulf of Lions (Northwestern Mediterranean margin). Geochim Cosmochim Acta $199: 222-237$.

Cresson P, Bouchoucha M, Miralles F, Elleboode R, Mahé K, Marusczak N, Thebault, Cossa D (2014a). Are red mullet efficient as bio-indicators of mercury contamination? A case study from the French Mediterranean? Mar Pollut Bull 91: 191-199. 
Cresson P, Fabri MC, Bouchoucha M, Brach Papa C, Chavanon F, Jadaud A, Knoery J, Miralles F, Cossa D (2014b). Mercury in organisms from the Northwestern Mediterranean slope: Importance of food sources. Sci Tot Environ 497-498: 229-238.

601 Cresson P, Bouchoucha M, Morat F, Miralles F, Chavanon F, Loizeau V, Cossa D (2015). A multitracer approach to assess the spatial contamination pattern of hake (Merluccius merluccius) in the French Mediterranean. Sci Tot Environ 532: 184-194.

Cresson P, Ruitton S, Harmelin-Vivien M (2016). Feeding strategies of co-occurring suspension feeders in an oligotrophic environment. Food Webs 6: 19-28.

De Pontual H, Groison AL, Pineiro C, Bertignac M (2006). Evidence of underestimation of European hake growth in the Bay of Biscay, and its relationship with bias in the agreed method of age estimation. ICES J Mar Sci 63: 1674-1681.

Espinasse B, Harmelin-Vivien M, Tiano M, Guilloux L, Carlotti F (2014). Patterns of variations in C and $\mathrm{N}$ stable isotope ratios in size-fractionated zooplankton in the Gulf of Lion, NW Mediterranean Sea. J Plankton Res 36: 1204-1215.

Fitzgerald WF, Lamborg CH, Hammerschmidt CR (2007). Marine biogeochemical cycling of mercury. Chem Rev 107: 641-662.

Goutte A, Bustamante P, Barbraud C, Delord K, Weimeskirch H, Chastel O (2014). Demographic responses to mercury exposure in two closely-related Antarctic top predators. Ecology 95:10751086.

Harmelin-Vivien M, Cossa D, Crochet S, Banaru D, Letourneur Y, Mellon-Duval C (2009).

Kehrig HA, Seixas TG, Baêta AP, Malm O, Moreira I (2010). Inorganic and methylmercury: Do they transfer along a tropical coastal food web? Mar Pollut Bull 60: 2350-2356.

Kerhervé P, Minagawa M, Heussner S, Monaco A (2001). Stable isotopes $\left({ }^{13} \mathrm{C} /{ }^{12} \mathrm{C}\right.$ and $\left.{ }^{15} \mathrm{~N} /{ }^{14} \mathrm{~N}\right)$ in settling organic matter of the northwestern Mediterranean Sea: biogeochemical implications. Oceanol Acta 24: S77-S85.

Kidd KA, Muir DCG, Evans MS, Wang X, Whittle M, Swanson HK, Johnston T, Guildford S (2012). Biomagnification of mercury through lake trout (Salvelinus namaycush) food webs of lakes with different physical, chemical and biological characteristics. Sci Tot Environ 438: 135-143.

Koutsikopoulos C, Le Cann B (1996). Physical processes and hydrological structures related to the Bay of Biscay anchovy. Sci Mar 60: 9-19. Canyon area (Bay of Biscay) during the ECOFER cruises. Deep-Sea Res II: 2057-2079. 
Lavoie RA, Jardine TD, Chumchal MM, Kidd KA, Campbell LM (2013). Biomagnification of mercury in aquatic food webs: A worldwide meta-analysis. Environ Sci Technol 47: 1338513394.

Le Faucheur S, Campbell PGC, Fortin C, Slaveykova VI (2014). Interactions between mercury and phytoplankton: Speciation, bioavailability, and internal handling. Environ Toxicol Chem 33: 1211-1224.

Lefevre D, Minas HJ, Minas M, Robinson C, Williams PJ Le B, Woodward EMS (1997). Review of gross community production, primary production, net community production and dark community respiration in the Gulf of Lions. Deep-Sea Res II 44: 801-832.

Le Moal M, Biegala IC (2009). Diazotrophic unicellular cyanobacteria in the northwestern Mediterranean Sea: a seasonal cycle. Limnol Oceanogr 54: 844-855.

Liénart C, Savoye N, Bozec Y, Breton E, Conan P, David V, Feunteun E, Grnagéré K, Kerhervé P, Lebreton B, Lefebvre S, et al. (2017). Dynamics of particulate organic matter composition in coastal systems: a spatio-temporal study at multi-systems scale. Prog Oceanogr 156: 221-239.

Longhurst A (1998). Ecological Geography Of The Sea, Vol. 1. Academic Press, London, 560 pp.

Mason RP, Rolfhus KR, Fitzgerald WF (1995). Methylated and elemental mercury cycling in surface and deep ocean waters of the North Atlantic. Wat Air Soil Pollut 80: 665-677.

Maulvault AL, Custódio A, Anacleto P, Repolho T, Pousão P, Nunes ML, Diniz M, Rosa R, Marques A (2016). Bioaccumulation and elimination of mercury in juvenile seabass (Dicentrarchus labrax) in a warmer environment. Environ Res 149: 77-85.

Mellon-Duval C, de Pontual H, Métral L, Quemener L (2009). Growth of European hake (Merluccius merluccius) in the Gulf of Lions based on conventional tagging. ICES J Mar Sci 67: 62-70.

Mèndez-Fernandez P, Pierce GJ, Bustamante P, Chouvelon T, Ferreira M, González AF, López A, Read F, Santos MB, Spitz J, Vingada JV, Caurant F (2013). Ecological niche segregation among five toothed whale species off the NW Iberian Peninsula using ecological tracers as multiapproach. Mar Biol 160: 2825-2840.

Monteiro LR, Costa V, Furness RW, Santos RS (1996). Mercury concentrations in prey fish indicate enhanced bioaccumulation in mesopelagic environments. Mar Ecol Prog Ser 141: 21-25.

Monteiro LR, Lopes HD (1990). Mercury content of swordfish, Xiphias gladius, in relation to length, weight, age, and sex. Mar Pollut Bull 21: 293-296.Pickhardt PC, Folt CL, Chen CY, Klaue B, Blum JD (2002). Algal blooms reduce the uptake of toxic methylmercury in freshwater food webs. Proc Natl Acad Sci USA 99: 4419-4423.

Montoya, J.P., 2007. Natural abundance of ${ }^{15} \mathrm{~N}$ in marine planktonic ecosystems. In: Michener, R., Lajtha, K. (Eds.), Stable Isotopes in Ecology and Environmental Science. Blackwell Publishing, pp. 76-201. 
671 Pierce GJ, Stowasser G, Hastie LC, Bustamante P (2008). Geographic, seasonal and ontogenetic variation in cadmium and mercury concentrations in squid (Cephalopoda: Teuthoidea) from UK waters. Ecotoxicol Environ Saf 70: 422-432.

674 Reygondeau G, longhurst A, Martinez E, Beaugrand G, Antoine D, Maury O (2013). Dynamic biogeochemical provinces in the global ocean. Global Biogeochem Cy 27: 1-13.

Signa G, Mazzola A, Tramati CD, Vizzini S (2017). Diet and habitat use influence Hg and Cd transfer to fish and consequent biomagnification in a highly contaminated area: Augusta Bay (Mediterranean Sea). Environ Pollut 230: 394-404.

679 Simoneau M, Lucotte M, Garceau S, Laliberte D (2005). Fish growth rates modulate mercury 680 concentrations in walleye (Sander vitreus) from eastern Canadian lakes. Environ Res 98: 73-82.

681 Tan SW, Meiller JC, Mahaffey KR (2009). The endocrine effects of mercury in humans and wildlife. Crit Rev Toxicol 39: 228-269.

683 Trudel M, Rasmussen JB (2006). Bioenergetics and mercury dynamics in fish: a modelling perspective. Can J Fish Aquat Sci 63: 1890-1902.

US EPA (2011). Exposure Factors Handbook 2011 Edition, Final Report. US Environmental Protection Agency, Washington, DC, EPA/600/R-09/052F.

687 Wang WX, Wong RSK (2003). Bioaccumulation kinetics and exposure pathways of inorganic mercury and methylmercury in a marine fish, the sweetlips Plectorhinchus gibbosus. Mar Ecol Prog Ser 257: 257-268.

690 Ward DM, Nislow KH, Chen CY, Folt CL. Reduced trace element concentrations in fast-growing 691 juvenile Atlantic salmon in natural streams. Environ Sci Technol 44: 3245-3251.

692 Zuur AF, Ieno EN, Smith GM (2007). Analysing Ecological Data. Springer, New York (USA). 

Table 1: Characteristics of fish and crustaceans considered in the NW Mediterranean (Gulf of Lion - GoL) and in the NE Atlantic (Bay of Biscay - BoB): sizes (in cm,) stable isotope ratios $\left(\delta^{13} \mathrm{C}\right.$ and $\delta^{15} \mathrm{~N}$ values in \%) and muscle total $\mathrm{Hg}\left(\mathrm{T}-\mathrm{Hg}\right.$ ) concentrations (in $\mu \mathrm{g} \mathrm{g}^{-1} \mathrm{dm}$ ) for the individuals analysed for the three parameters ( $\left.\mathrm{N}=134\right)$; sizes (in $\mathrm{cm}$ ), methyl- $\mathrm{Hg}$ (Me-Hg) concentrations (in $\mu \mathrm{g} \mathrm{g}^{-1} \mathrm{dm}$ ) and $\mathrm{MeHg} / \mathrm{T}-\mathrm{Hg}$ ratio (in \%) for the subsample of individuals analysed for Me-Hg concentrations ( $\mathrm{n}=75$ ). The water content (WC) of the muscle tissue (in \%), either derived from dedicated individual measures (for five of the seven Atlantic species) or from the general literature (US EPA, 2011; in brackets) is also indicated, for further conversion of $\mathrm{Hg}$ concentrations in wet mass if needed (i.e. for comparison with seafood $\mathrm{Hg}$ standards). (nd) $=$ not determined.

\begin{tabular}{|c|c|c|c|c|c|c|c|c|c|c|c|}
\hline Ecosystem & $\mathbf{N}$ & $\begin{array}{c}\text { Size }^{\mathrm{a}} \\
\text { Mean } \pm \text { SD } \\
(\min , \max )\end{array}$ & $\begin{array}{c}\delta^{13} \mathrm{C} \\
\operatorname{Mean} \pm \mathrm{SD} \\
(\min , \max )\end{array}$ & $\begin{array}{c}\delta^{15} \mathrm{~N} \\
\text { Mean } \pm \text { SD } \\
(\min , \max )\end{array}$ & $\begin{array}{c}\text { T-Hg } \\
\text { Mean } \pm \text { SD } \\
(\min , \max )\end{array}$ & $\begin{array}{l}\text { WC, measured } \\
\text { Mean } \pm \text { SD } \\
(\text { min, max) }\end{array}$ & $\begin{array}{c}\text { WC, } \\
\text { US EPA } 2011 \\
\text { Mean } \\
\text { ("Raw" tissue) }\end{array}$ & $\mathbf{n}$ & $\begin{array}{c}\text { Size }^{\mathrm{a}} \\
\text { (subsampling) } \\
\text { Mean } \pm \text { SD } \\
(\min , \max )\end{array}$ & $\begin{array}{c}\text { Me-Hg } \\
\text { Mean } \pm \text { SD } \\
(\min , \max )\end{array}$ & $\begin{array}{c}\text { Me-Hg/T-Hg } \\
\text { ratio } \\
\text { Mean } \pm \text { SD } \\
(\min , \max )\end{array}$ \\
\hline NW Mediterranean (GoL) & 72 & & & & & & & 37 & & & \\
\hline \multicolumn{12}{|l|}{ Cartilaginous fish } \\
\hline Scyliorhinus canicula (Sc) & 9 & $\begin{array}{l}48 \pm 5 \\
(41,57)\end{array}$ & $\begin{array}{l}-18.0 \pm 0.2 \\
(-18.4,-17.8)\end{array}$ & $\begin{array}{l}8.9 \pm 0.2 \\
(8.7,9.3)\end{array}$ & $\begin{array}{l}10.85 \pm 7.62 \\
(4.63,27.01)\end{array}$ & (nd) & (73.6) & 6 & $\begin{array}{c}50 \pm 5 \\
(41,57)\end{array}$ & $\begin{array}{l}11.61 \pm 8.45 \\
(4.95,27.07)\end{array}$ & $\begin{array}{c}99 \pm 5 \\
(93,107)\end{array}$ \\
\hline Galeus melastomus $(\mathrm{Gm})$ & 15 & $\begin{array}{c}46 \pm 6 \\
(33,56)\end{array}$ & $\begin{array}{c}-18.0 \pm 0.3 \\
(-18.4,-17.2)\end{array}$ & $\begin{array}{c}8.9 \pm 0.6 \\
(7.8,10.2)\end{array}$ & $\begin{array}{c}7.81 \pm 4.02 \\
(3.37,16.72)\end{array}$ & (nd) & (73.6) & 6 & $\begin{array}{c}48 \pm 3 \\
(43,51)\end{array}$ & $\begin{array}{c}8.59 \pm 3.94 \\
(3.44,13.25)\end{array}$ & $\begin{array}{c}101 \pm 7 \\
(91,112)\end{array}$ \\
\hline \multicolumn{12}{|l|}{ Teleost fish } \\
\hline Helicolenus dactylopterus (Hd) & 13 & $\begin{array}{c}26 \pm 3 \\
(20,31)\end{array}$ & $\begin{array}{c}-18.3 \pm 0.5 \\
(-19.0,-17.5)\end{array}$ & $\begin{array}{c}9.2 \pm 0.8 \\
(7.9,10.2)\end{array}$ & $\begin{array}{c}7.83 \pm 2.97 \\
(4.24,12.92)\end{array}$ & (nd) & (79.3) & 6 & $\begin{array}{c}27 \pm 3 \\
(22,31)\end{array}$ & $\begin{array}{c}7.20 \pm 3.26 \\
(3.49,11.46)\end{array}$ & $\begin{array}{c}93 \pm 7 \\
(82,103)\end{array}$ \\
\hline Lepidorhombus boscii (Lb) & 5 & $\begin{array}{c}26 \pm 5 \\
(20,33)\end{array}$ & $\begin{array}{c}-18.6 \pm 0.2 \\
(-18.9,-18.4)\end{array}$ & $\begin{array}{l}8.2 \pm 0.3 \\
(7.9,8.6)\end{array}$ & $\begin{array}{l}4.96 \pm 2.66 \\
(2.33,9.30)\end{array}$ & (nd) & $(79.1)$ & 4 & $\begin{array}{l}28 \pm 4 \\
(24,33)\end{array}$ & $\begin{array}{l}5.13 \pm 3.36 \\
(1.89,9.59)\end{array}$ & $\begin{array}{c}94 \pm 12 \\
(81,105)\end{array}$ \\
\hline Phycis blennoides $(\mathrm{Pb})$ & 15 & $\begin{array}{c}27 \pm 5 \\
(20,38)\end{array}$ & $\begin{array}{c}-18.8 \pm 0.5 \\
(-19.8,-17.9)\end{array}$ & $\begin{array}{c}9.4 \pm 0.7 \\
(7.1,10.1)\end{array}$ & $\begin{array}{l}2.63 \pm 1.03 \\
(1.14,4.21)\end{array}$ & (nd) & $(81.2)$ & 6 & $\begin{array}{c}29 \pm 4 \\
(23,34)\end{array}$ & $\begin{array}{l}2.77 \pm 0.57 \\
(2.25,3.84)\end{array}$ & $\begin{array}{c}93 \pm 2 \\
(90,96)\end{array}$ \\
\hline Micromesistius poutassou $(\mathrm{Mp})$ & 12 & $\begin{array}{c}26 \pm 3 \\
(22,31)\end{array}$ & $\begin{array}{c}-19.0 \pm 0.6 \\
(-20.5,-18.3)\end{array}$ & $\begin{array}{l}8.6 \pm 0.4 \\
(8.0,9.4)\end{array}$ & $\begin{array}{l}1.53 \pm 0.45 \\
(0.90,2.41)\end{array}$ & (nd) & $(80.3)$ & 6 & $\begin{array}{c}26 \pm 3 \\
(23,31)\end{array}$ & $\begin{array}{l}1.36 \pm 0.56 \\
(0.74,2.27)\end{array}$ & $\begin{array}{c}86 \pm 5 \\
(81,94)\end{array}$ \\
\hline \multicolumn{12}{|l|}{ Crustaceans } \\
\hline Nephrops norvegicus (Nn) & 3 & $\begin{array}{l}4.7 \pm 0.4 \\
(4.3,5.0)\end{array}$ & $\begin{array}{c}-18.8 \pm 0.4 \\
(-19.1,-18.3)\end{array}$ & $\begin{array}{l}7.0 \pm 0.3 \\
(6.7,7.2)\end{array}$ & $\begin{array}{l}3.11 \pm 0.50 \\
(2.69,3.66)\end{array}$ & (nd) & (76.8) & 3 & $\begin{array}{l}4.7 \pm 0.4 \\
(4.3,5.0)\end{array}$ & $\begin{array}{l}2.86 \pm 0.51 \\
(2.38,3.40)\end{array}$ & $\begin{array}{c}92 \pm 3 \\
(89,94)\end{array}$ \\
\hline
\end{tabular}




\section{Cartilaginous fish}

Scyliorhinus canicula $(\mathrm{S}$

10

$58 \pm$

$-16.7 \pm 0.2$

$13.1 \pm 0.3$

Galeus melastomus (Gm)

12

\section{$61 \pm 7$}

$-17.2 \pm 0.2$

$(12.6,13.5)$

$(0.93,4.63)$

$(76.0,78.2)$

6

$57 \pm 2$

$(54,60)$

$1.98 \pm 0.74$

$(1.18,3.03)$

$94 \pm 4$

$\begin{array}{lll}12.1 \pm 0.6 & 2.19 \pm 1.38 & 78.3 \pm 0.4\end{array}$

$(1.04,5.12) \quad(77.7,78.9)$

(73.6)

6

$63 \pm 8$

$2.51 \pm 1.56$

$(0.95,4.53)$

$94 \pm 6$

$(89,105)$

\section{Teleost fish}

Helicolenus dactylopterus (Hd)

5

$37 \pm 2$

$-17.3 \pm 0.12013 .2 \pm 0.3$

$4.77 \pm 0.84$

$79.6 \pm 0.6$

$(-17.5,-17.2) \quad(12.7,13.6) \quad(3.89,6.13) \quad(78.7,80.2)$

Lepidorhombus boscii (Lb)

$30 \pm 3$

$-16.8 \pm 0.1$

$11.5 \pm 0.3$

$2.32 \pm 1.80$

$(0.82,4.29)$

(nd)

$(-17.0,-16.6)$

$(11.2,11.9)$

$0.96 \pm 0.72$

$(0.36,1.80)$

(nd)

$(-17.4,-16.7)$

$13.5 \pm$

$0.25+0.22$

$-18.1 \pm 0.4$

$11.5 \pm 0.6$

$(0.08,0.77)$

$(-19.1,-17.1)$

$(10.1,13.0)$

$(76.7,79.8)$

$0.62 \pm 0.07$

$(0.55,0.69)$

$78.3 \pm 1.3$

$(76.9,80.0)$

${ }^{a}$ Total length for fish, cephalothorax length for crustaceans.

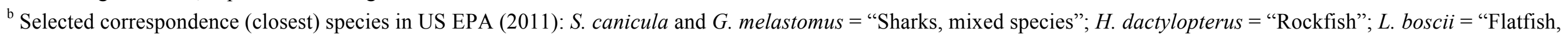
Flounder, and Sole"; P. blennoides = "Cod, Atlantic"; M. poutassou = "Whiting, mixed species"; N. norvegicus = "Lobster, northern". 
Table 2: Results of the final GLM models explaining (log-transformed) $\mathrm{T}-\mathrm{Hg}$ or $\mathrm{Me}-\mathrm{Hg}$ concentrations' variability in the muscle of the seven selected species. Akaike Information Criterion (AIC) values and the total deviance explained (DE) by each model are indicated (see section 2.4). Estimates and significance ( $\mathrm{p}$-values) for each term included are also given. ${ }^{*} \mathrm{p}<0.05 ; * * \mathrm{p}<0.01$; $* * * \mathrm{p}<0.001$.

\begin{tabular}{|c|c|c|c|}
\hline & $\begin{array}{c}\text { Variables } \\
(\text { equation terms) }\end{array}$ & Estimates & p-value \\
\hline \multirow[t]{2}{*}{$\mathbf{T}-\mathbf{H g}(\mathrm{N}=134)$} & \multicolumn{3}{|c|}{$\begin{array}{c}\log _{\mathbf{1 0}}[\mathbf{T}-\mathbf{H g}]=\boldsymbol{\delta}^{\mathbf{1 5}} \mathbf{N}+\mathbf{E c o s y s t e m}+\boldsymbol{\delta}^{\mathbf{1 5}} \mathbf{N}: \text { Ecosystem } \\
\text { AIC }=138.8 \\
\text { Total DE }=53.8 \%\end{array}$} \\
\hline & $\begin{array}{c}\text { Intercept } \\
\delta^{15} \mathrm{~N} \\
\text { MED-GoL (relative to ATL-BoB) } \\
\left.\delta^{15} \mathrm{~N}: \text { MED-GoL (relative to } \delta^{15} \mathrm{~N}: A T L-B o B\right)\end{array}$ & $\begin{array}{l}(\alpha)-4.4378 \\
\left(\beta_{1}\right) 0.3573 \\
4.0925 \\
-0.2484\end{array}$ & $\begin{array}{l}<0.001^{* * *} \\
<0.001^{* * *} \\
<0.001^{* * *} \\
0.0034^{* *}\end{array}$ \\
\hline \multirow[t]{2}{*}{ Me-Hg $(n=75)$} & \multicolumn{3}{|c|}{$\begin{array}{c}\log _{10}[\mathbf{M e}-\mathbf{H g}]=\delta^{15} \mathbf{N}+\text { Ecosystem } \\
\text { AIC }=78.0 \\
\text { Total DE }=44.7 \%\end{array}$} \\
\hline & $\begin{array}{c}\text { Intercept } \\
\delta^{15} \mathrm{~N} \\
\text { MED-GoL (relative to ATL-BoB) }\end{array}$ & $\begin{array}{l}(\alpha)-2.5701 \\
\left(\beta_{1}\right) 0.2136 \\
0.9858\end{array}$ & $\begin{array}{l}<0.001^{* * *} \\
<0.001^{* * *} \\
<0.001^{* * *}\end{array}$ \\
\hline
\end{tabular}

${ }^{a}$ When the interaction term is not significant (i.e. model assuming that the form of the relationship between ecosystems is the same, for Me- $\mathrm{Hg}$ ), the underlying model's specifications are:

(Eq. 1) $\log _{10}[\mathrm{Me}-\mathrm{Hg}]_{\mathrm{i}}=\alpha+\beta_{1} * \delta^{15} \mathrm{~N}_{\mathrm{i}}+$ Ecosystem $_{\mathrm{i}}+\varepsilon_{\mathrm{i}}$

When the interaction is significant (i.e. for $\mathrm{T}-\mathrm{Hg}$, form of the relationship different between ecosystems), the model's specifications are:

(Eq. 2) $\log _{10}[\mathrm{~T}-\mathrm{Hg}]_{\mathrm{i}}=\alpha+\beta_{1} * \delta^{15} \mathrm{~N}_{\mathrm{i}}+$ Ecosystem $_{\mathrm{i}}+\delta^{15} \mathrm{~N}_{\mathrm{i}}:$ Ecosystem $_{\mathrm{i}} * \delta^{15} \mathrm{~N}_{\mathrm{i}}+\varepsilon_{\mathrm{i}}$

In equations (Eq. 1) and (Eq. 2), the terms correspond to:

- $\log _{10}[\mathrm{~T}-\mathrm{Hg} \text { or } \mathrm{Me}-\mathrm{Hg}]_{\mathrm{i}}=$ the log-transformed concentration in $\mathrm{T}-\mathrm{Hg}$ or Me-Hg for sample $\mathrm{i}$;

$-\alpha=$ intercept for the relationship;

$-\beta_{1}=$ the estimate for the continuous explanatory variable $\delta^{15} \mathrm{~N}$;

$-\delta^{15} \mathrm{~N}_{\mathrm{i}}=$ the $\delta^{15} \mathrm{~N}$ value for sample i;

- Ecosystem ${ }_{i}=$ correction to apply for the ecosystem(s) of concern if necessary, here for MED-GoL (see below);

$-\varepsilon=$ residuals (i.e. information not explained by the model).

When the interaction is not significant in the model (i.e. for Me-Hg), predicted values (fitted model) derived from model outputs can thus be deduced as follow:

- $\log _{10}[\mathrm{Me}-\mathrm{Hg}]_{\mathrm{i}}$ for ATL-BoB (i.e. first modality of the factor Ecosystem) $=\alpha+\beta_{1} * \delta^{15} \mathrm{~N}_{\mathrm{i}}$

- $\log _{10}[\mathrm{Me}-\mathrm{Hg}]_{\mathrm{i}}$ for MED-GoL (i.e. second modality of the factor Ecosystem) $=\alpha+\beta_{1} * \delta^{15} \mathrm{~N}_{\mathrm{i}}+$ estimate for MED-GoL

When the interaction is significant, it is in the form (i.e. for $\mathrm{T}-\mathrm{Hg}$ ):

- $\log _{10}[\mathrm{~T}-\mathrm{Hg}]_{\mathrm{i}}$ for ATL-BoB $=\alpha+\beta_{1} * \delta^{15} \mathrm{~N}_{\mathrm{i}}$

- $\log _{10}[\mathrm{~T}-\mathrm{Hg}]_{\mathrm{i}}$ for MED-GoL $=\alpha+\beta_{1} * \delta^{15} \mathrm{~N}_{\mathrm{i}}+$ estimate for MED-GoL + estimate for the interaction term $\delta^{15} \mathrm{~N}: \mathrm{MED}-\mathrm{GoL} * \delta^{15} \mathrm{~N}_{\mathrm{i}}$

In fact, in the model outputs of predicted values, the estimates for the first modality of the factor Ecosystem (i.e. ATL-BoB) are equal to 0 because the model uses this first modality as baseline (Zuur et al., 2007). Estimates for the modality MED-GoL thus correspond to the correction applying to this modality, relative to the modality ATL-BoB. 


\section{Caption to figures:}

Figure 1: Maps of the sampling areas and of trawling stations in the NW Mediterranean (MED - Gulf of Lion) and in the NE Atlantic (ATL - Bay of Biscay).

Figure 2: a) Boxplots of sizes (total length for fish, cephalothorax length for crustaceans) for the seven species analysed in the NW Mediterranean - Gulf of Lion (MED - GoL) and in the NE Atlantic - Bay of Biscay (ATL - BoB) $(\mathrm{N}=134)$; b) Boxplots of muscle total $\mathrm{Hg}$ ( $\mathrm{T}-\mathrm{Hg}$ ) concentrations $(\mathrm{N}=134)$; c) Biplot of $\delta^{13} \mathrm{C}$ and $\delta^{15} \mathrm{~N}$ values $(\mathrm{N}=134)$; d) Boxplots of percentages of Me-Hg (i.e. ratios $\mathrm{Me}-\mathrm{Hg} / \mathrm{T}-\mathrm{Hg}$, in \%) in the muscle of the subsample of individuals analysed for Me-Hg concentrations $(n=75)$.

For boxplots $(a, b, d)$, the box length represents the interquartile, the bar length represents the range, and the horizontal lines in bold are median values. For each species, the significant difference between systems is indicated (tested by Student t-test or Mann-Whitney-Wilcoxon test, depending on data satisfying conditions for parametric statistics or not). ${ }^{*} \mathrm{p}<0.05 ;{ }^{* *} \mathrm{p}<0.01 ; * * * \mathrm{p}<0.001$; NS $=$ non significant. For the biplot (c), values are mean \pm standard deviation per species. Abbreviations for species are specified in Table 1.

Figure 3: Relationship between muscle methyl-Hg (Me- $\mathrm{Hg}$ ) and total $\mathrm{Hg}(\mathrm{T}-\mathrm{Hg}$ ) concentrations for the subsample of individuals analysed for Me- $\mathrm{Hg}$ concentrations $(\mathrm{n}=75)$, and for the seven species analysed in the NW Mediterranean - Gulf of Lion (MED - GoL) and in the NE Atlantic - Bay of Biscay (ATL - BoB). The correspondence line 1:1 is indicated, as well as the results of the nonparametric Spearman correlation coefficient test. Symbols used for species are the same than in Fig. 2c.

Figure 4: Relationships between individual log-transformed total $\mathrm{Hg}$ ( $\mathrm{T}-\mathrm{Hg}$ ) concentrations (left panel, $\mathrm{N}=134$ ) or methyl-Hg $(\mathrm{Me}-\mathrm{Hg})$ concentrations (right panel, $\mathrm{n}=75)$, and $\delta^{15} \mathrm{~N}$ values (as a proxy of the trophic level within a given systems), for the seven species analysed in the NW Mediterranean Gulf of Lion (MED - GoL) and in the NE Atlantic - Bay of Biscay (ATL - BoB). The symbology used for each species is the same as in Fig. 2c. Results from the GLMs (lines) are plotted on observed $\log$-transformed data. When the interaction term was not significant (i.e. for $\mathrm{MeHg}$, the model assumes that the form of the relationship is not different between the ecosystems), lines are parallel (i.e. same slope, although different intercept). This can also be interpreted (i.e. slope of the lines) as the biomagnification power of T-Hg or Me-Hg within each ecosystem considered (as performed by Cossa et al., 2012, for Me-Hg). Finally, the equations of lines (derived from model outputs; Table 2) are indicated. 


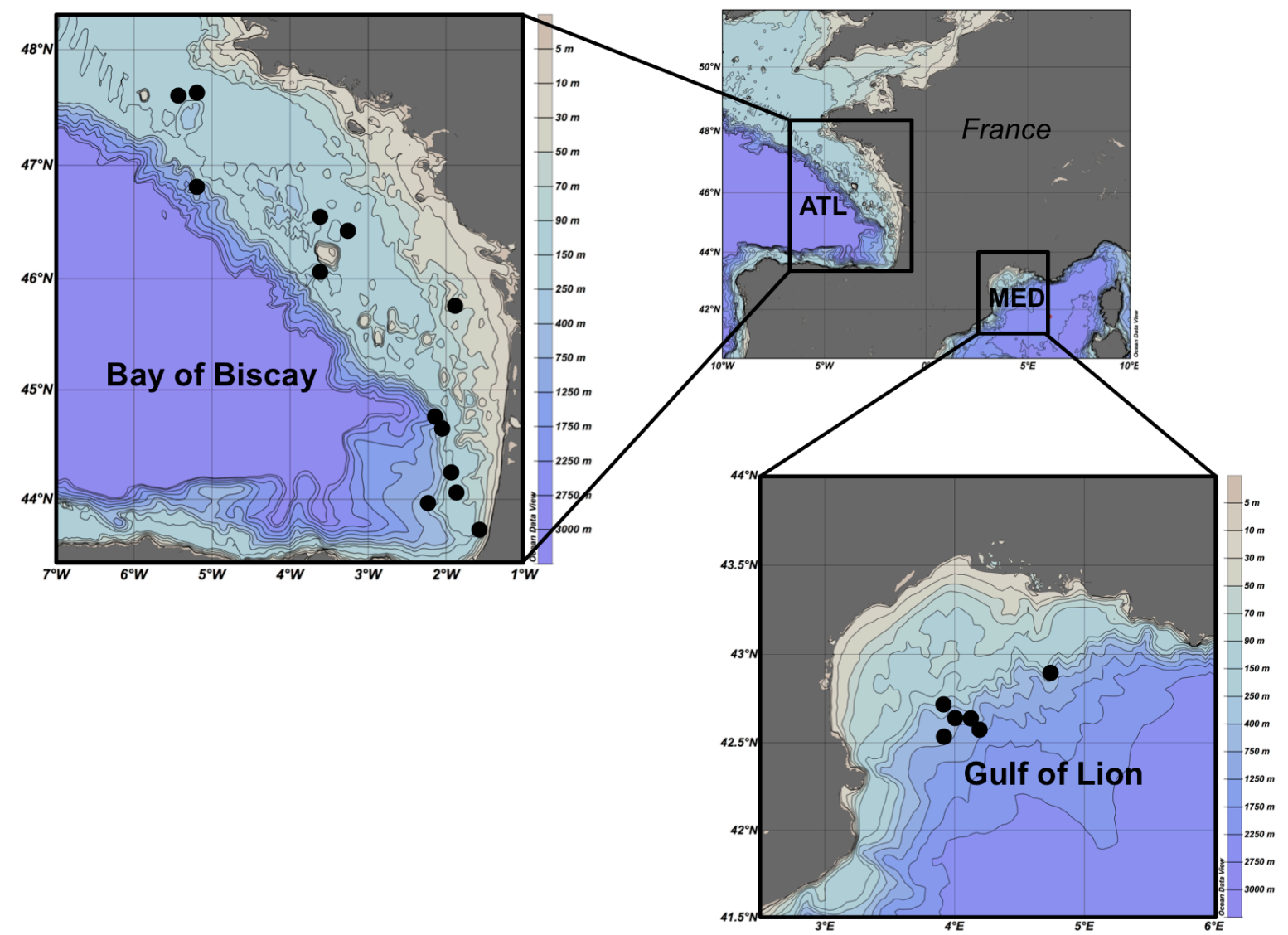

Figure 1 

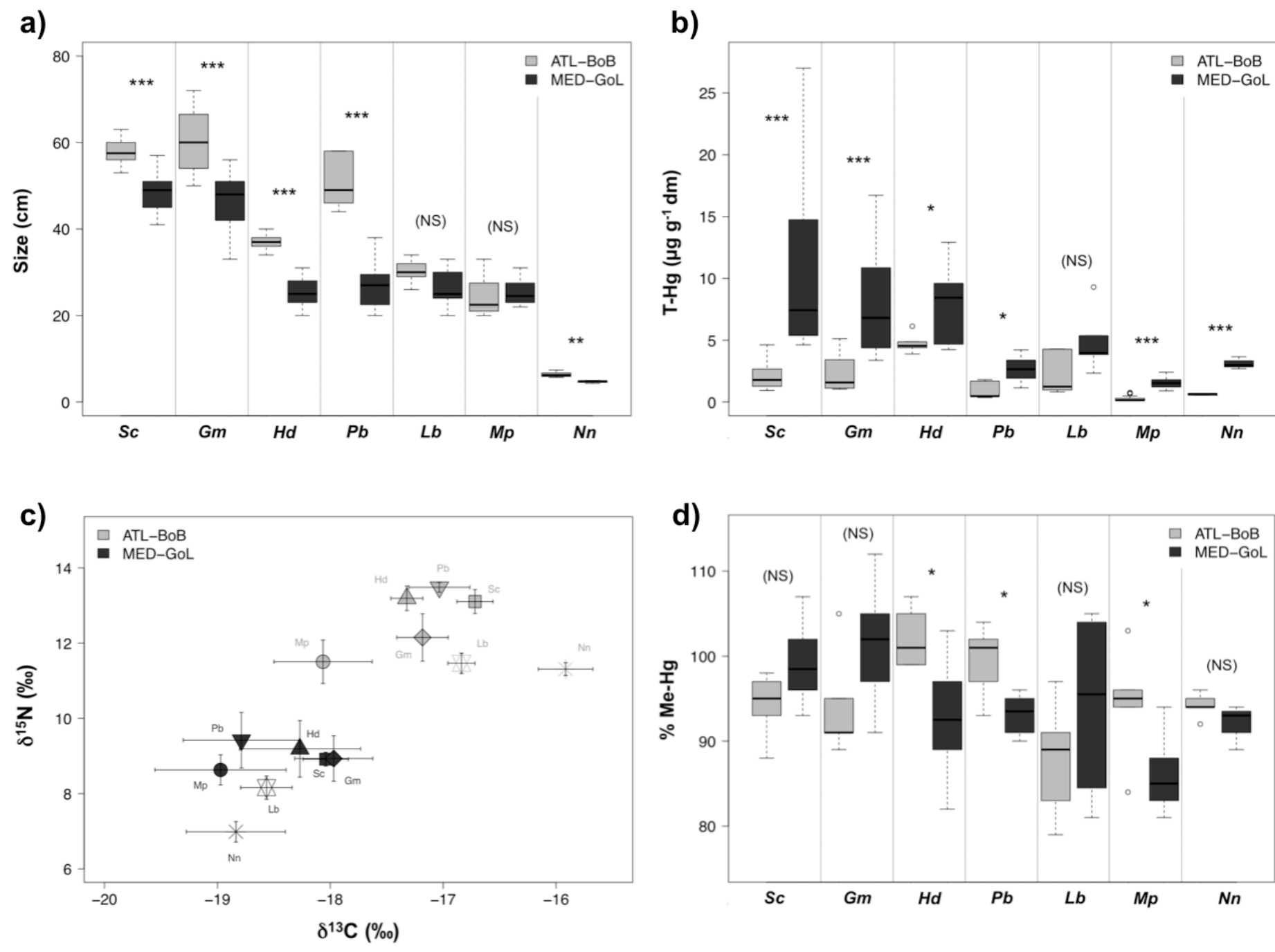

Figure 2 


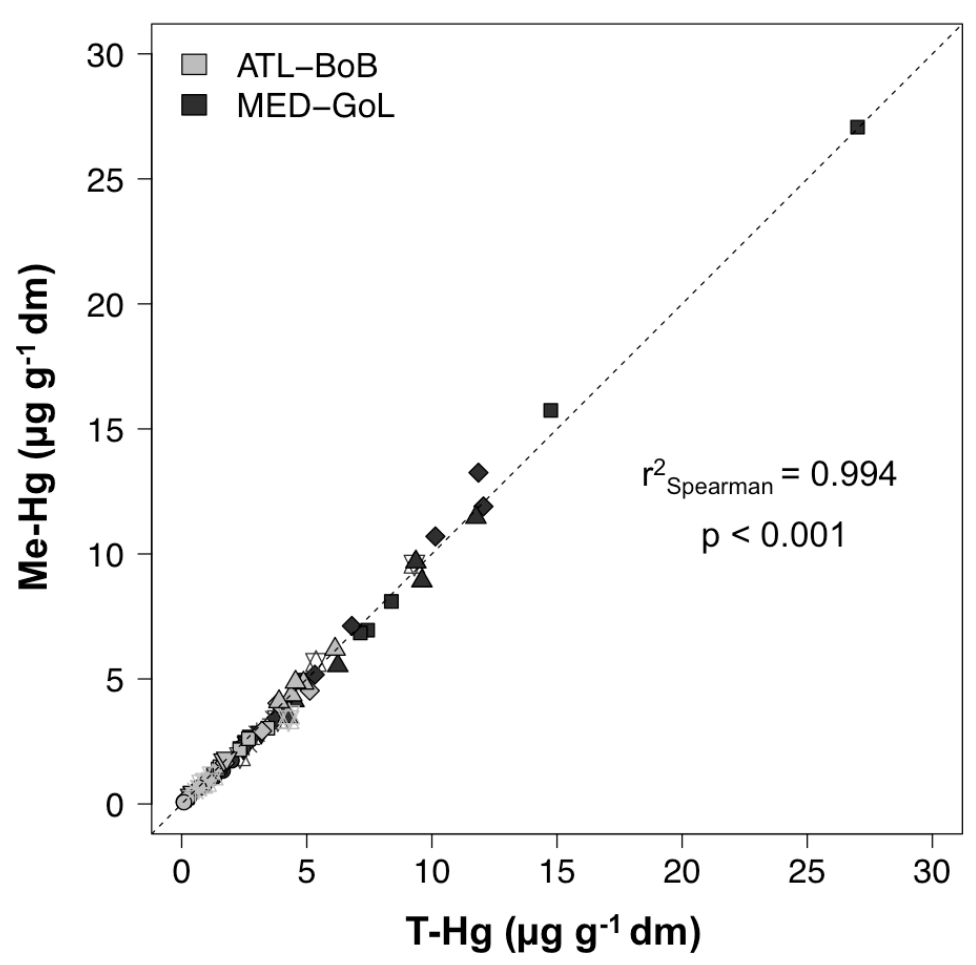

Figure 3 

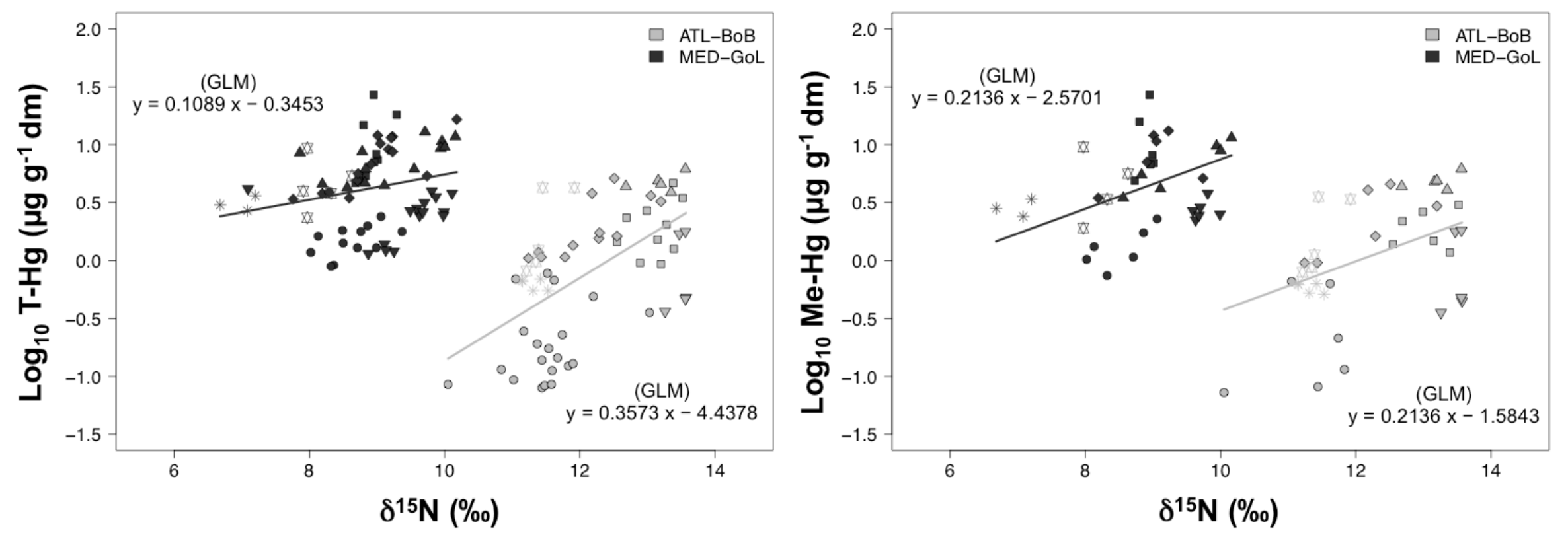

Figure 4 